\title{
RECENT GOVERNMENT PUBLICATIONS OF POLITICAL INTEREST
}

\author{
BY CARL HOOKSTADT
}

\section{UNITED STATES 2}

Alsop Claim. The case of the United States for and in behalf of the original American claimants in this case versus the Republic of Chile before His Majesty George V, under the protocol of Dec. 1, 1910. 5 vols.

Case of the United States, $1 \mathrm{v}$. Appendix to case of the United States, $2 \mathrm{v}$. Counter case of the United States, $1 \mathrm{v}$. Appendix to counter case of the United States, $1 \mathrm{v}$.

Arbitration with France signed Aug. 3, 1911. 1911. 6p. $8^{\circ}$. State dept. (S. doc. 92.)

Arbitration with Great Britain signed Aug. 3, 1911. 1911. 6p. $8^{\circ}$. State dept. (S. doc. 91.)

Arbitration Treaties with Great Britain and France signed Aug. 3, 1911. Report of Committee on Foreign Relations, together with views of minority and proposed committee amendments. 1911. 40p. $8^{\circ}$. Senate. Committee on Foreign Relations. (S. doc. 98.)

British Tarift Commission. Report of most-favored-nation agreements in relation to the proposed reciprocal trade agreement between Canada and the United States. 1911. 19p. $8^{\circ}$. Senate. (S. doc. 66.)

Bureau of Labor, Bulletin Nos. 92-93. Jan. and Mar., 1911.

No. 92 contains: Industrial accidents and loss of earning power; German experience in 1897 and 1907, by Henry J. Harris: Workmen's compensation and insurance; laws and bills, 1911, by Lindley D. Clark: Resolutions of the sixth delegates' meeting of the International association of labor legislation.

No. 93 contains: Wholesale prices, 1890 to 1910; Abstracts of British Board of Trade reports on cost of living; Hours of labor of men, women and children employed in factories in Austria; Decisions of courts affecting labor.

Chamizal Arbitration. (United States and Mexico.)

Case of the United States, 1v. Counter case of the United States, 1v. Appendix to counter case of the United States, 1v. Argument of the United States, 1v.

Chamizal Arbitration. Brief presented by the government of the United States of Mexico to the agent of the government of the United States of America in accordance of article $V$ of the arbitration convention, June 24, 1910. 1911.

Constitution of the United States, Some defects in. Address by the Hon. Walter Clark, chief justice of North Carolina, to the law department of the University of Pennsylvania, on April 27, 1906. 1911. 17p. $8^{\circ}$. Senate. (S. doc. 87.)

${ }^{2}$ All numbered documents refer to $62 \mathrm{~d}$ Congress unless otherwise specified. 
Customs Tariff of 1842 with senate debates thereon, accompanied by messages of the president, treasury reports, and bills. 1911. 593p. $8^{\circ}$. Senate. (S. doc. 21.)

Includes tariffs from 1789 to 1833 , with the votes in each House of Congress thereon arranged according to states.

Customs Tarlff of 1846 with senate debates thereon, accompanied by messages of the president, treasury reports, and bills. 1911. 426p. $8^{\circ}$. Senate. (S. doc. 71.)

Eight-Hour Law. Report of committee to accompany H. R. 9061. 1911. 29p. $8^{\circ}$. House. Committee on Labor. (H. rpt. 165.)

Employers' Liabillty and Workmen's Compensation Commission. Hearings. 2 vols. 1911. (S. doc. 90.)

German Bank Inquiry of 1908-09. v. 2. 1911. National Monetary Commission. (61st Cong., S. doc. 407.)

v. 2. Proceedings of the entire commission on point VI of the question sheet (the deposit system).

Hawall, Fourth report of the Commissioner of Labor on, 1910. 1911. 465p. $8^{\circ}$. Bureau of Labor. (61st Cong., S. doc. 866.)

Contains: Sugar industry; income and cost of living of workpeople in Honolulu; immigration; Japanese strike of 1909.

Manufactures of Cotton, Report submitted by Mr. Underwood, from the Committee on Ways and Means, on the bill H. R. 12812, to reduce the duties on. 1911. 539p. $8^{\circ}$. House. Committee on Ways and Means. (H. doc. 65.)

Pan-American Commercial Congress. Proceedings. Held Feb., 1911, Washington, D. C. 330p. $8^{\circ}$. Pan-American Union.

Reciprocity with Canada. Hearings on H. R. 4412. 1911. $8^{\circ} .2$ vols. Senate. Committee on Finance. (S. doc. 56.)

Retirement of Superannuated Civil Service Employees, Savings and annuity plan proposed for. By Herbert D. Brown. 1911. 225p. $8^{\circ}$. Senate. (61st Cong., S. doc. 745.)

Sherman Act, Recent interpretation of. An address before the Michigan state bar association, July 6, 1911. 18p. $8^{\circ}$. Senate. (S. doc. 83.)

Tariff Proceedings and Documents, 1839-1857, accompanied by messages of the president, treasury reports, and bills. 1911. 3 vols. Senate. (S. doc. 72.)

Woman and Child Wage-Earners in the United States, Report on condition of (report to consist of 19 vols.) 1911. Bureau of Labor. (61st Cong., S. doc. 645.) v. 9. Employment of women in the metal trades.

\section{GREAT BRITAIN 1}

Alsace-Lorraine. Translation of the laws relating to the grant of a constitution. Misc. No. 9 (1911). 9p. fol. Foreign Office. (cd. 5804.) 1 1-2d.

Alsop Claim. Award pronounced by H. M. King George V as "amiable compositeur" between United States and Chile. Chile No. 1 (1911). 17 p. (cd. 5739.) 2 1-2d.

1The British Parliamentary papers may be purchased from Wyman \& Sons, Ltd., Fetter Lane, E. C., London. Cd. refers to papers presented to Parliament by command. 
Company Laws in the British Empire. Comparative analysis of the company laws of the United Kingdom, India, Canada, Australia, New Zealand and South Africa, with a memorandum prepared for the Imperial Conference, 1911. 42p. fol. Board of Trade. (cd. 5864.) 4 1-2d.

Earnings and Hours of Labour of workpeople of the United Kingdom, Report of an enquiry by the Board of Trade into. 1911. Board of Trade. (cd. 5814.) 2s. v. 6. Metal, engineering and building trades in 1906 .

Imperial Conference, 1911. Précis of the proceedings. 1911. 85p. fol. (cd. 5741.) 8 1-2d.

Imperial Conference, 1911. Dominions No. 7. Minutes of the proceedings. Papers laid before the conference are printed separately in [cd. 5746-1] and [cd. 5746-2]. 1911. ii, 441p. fol. (cd. 5745.) 3s. 6d.

Partial list of subjects discussed: Imperial council, reconstitution of Colonial office, declaration of London, labour exchanges, enforcement of arbitration awards, interchange of civil servants, withdrawal of dominions from rxisting commercial treaties, navigation law, law of conspiracy.

Local Government. Report from the joint select committee on the local government acts, 1888 and 1894, and the local government (Scotland) acts, 1889 and 1894 (financial adjustments) together with the proceedings of the committee, minutes of evidence and appendices. 1911. xxviii, 408p. fol. (H. of C. Paper 246, 1911.) 3s. $6 d$.

Moral and Material Progress and Condition of India, Statement exhibiting the, 1909-10. 1911. 138p. fol. India Office. (H. of C. Paper 179, 1911.) 1s. $2 d$.

Payment of Members of Foreign Parliaments, Reports from H. M. representatives abroad respecting. Misc. No. 7. (1911). 17p. fol. Foreign Office. (cd. 5714.) 2 1-2d.

Referendum in Australia, Papers with reference to. 1911. 11p. fol. (cd. 5778.) 1 1-2d.

Tuberculosis (Human and Animal). Final report of royal commission. Part 1, report. (cd. 5761.) 6s. 7 1-2d.

\section{FRANCE}

Documents Diplomatiques. Deuxième conférence internationale pour la répression de la traite des blanches (18 avril-4 mai 1910). 1910. 108p. fol. Ministère des affaires étrangères.

Documents Diplomatiques. Conférence internationale de la Haye pour l'unification du droit relatif à la lettre de change et au billet à ordre (23 juin-25 juill 1910). 1910. 110p. fol. Ministère des affaires étrangères.

Documents Diplomatiques. Conférence internationale relative à la circulation des automobiles. 1910. 108p. fol. Ministère des affairs étrangères.

Documents Diplomatiques. Conférence internationale relative à la répression de la circulation des publications obscènes (18 avril-4 mai 1910). 1910. 148p. fol. Ministère des affaires étrangères.

Résumé général des travaux législatif́s de la Chambre des Députés depuis la mise en vigueur déshois constitutionnelles de 1875 jusqu'à la réunion de la dixième législature (du 8 mars 1876 au 31 mai 1910). Recueil contenant, avec la nomen- 
clature des principaux projets adoptés par la Chambre des Députés, les élections successives et les portraits des membres de la 10e législature. $1911 . \quad 1324 \mathrm{p} . \quad 8^{\circ}$.

Résumé général des travaux législatifs de la Chambre des Députés pendant la neuvième législature (1906-10). LXV fascicule. 1910. xvii, 877p. $8^{\circ}$.

\section{ITALY}

Il probivirato in Italia nel quinquennio 1906-1910. Esistenza, funzionamento e massimario dei collegi con una raccolta di massime di giurisprudenza estera in materia di lavoro. Pubblicazione fatte in occasione del II congresso dei probiviri italiani in Roma. 1911. xvi, 248p. fol. Ufficio del lavoro.

Materiali per lo studio delle relazioni tra le classi agrarie in Romagna (1905-10). 1911. Ufficio del lavoro.

\section{PRUSSIA}

Verwaltung der Oeffentlichen Arbeiten in Preussen 1900 bis 1910.1911. $\mathrm{xi}, 370 \mathrm{p} . \quad 4^{\circ}$. Ministerium fur affentlichen arbeiten. 